\title{
Information and the Indian State: A Genealogy
}

\section{Biswarup Sen}

\section{(2) OpenEdition}

1 Journals

Electronic version

URL: http://journals.openedition.org/samaj/6377

DOI: 10.4000/samaj.6377

ISSN: $1960-6060$

Publisher

Association pour la recherche sur l'Asie du Sud (ARAS)

\section{Electronic reference}

Biswarup Sen, «Information and the Indian State: A Genealogy », South Asia Multidisciplinary Academic Journal [Online], 23 | 2020, Online since 20 March 2020, connection on 16 September 2020. URL :

http://journals.openedition.org/samaj/6377 ; DOI : https://doi.org/10.4000/samaj.6377

This text was automatically generated on 16 September 2020 .

\section{(c) $($ ) $(9)$}

This work is licensed under a Creative Commons Attribution-NonCommercial-NoDerivatives 4.0

International License. 


\title{
Information and the Indian State: A Genealogy
}

\author{
Biswarup Sen
}

1 The concept of "information" has been at the heart of notions about citizenship in contemporary societies. For example, in one of the world's oldest modern democracies -the United States-the very process of democracy was considered to hinge on the ability of the nation to count and tabulate the entirety of its citizens (Lepore 2018, Koopman 2019). As Michel Foucault (1975) seminally argued the passage to modernity is characterized by the rise of bio-power, that is, by the tendency of the modern state to think of its citizenry as a "population" that needs to be comprehended and governed by means of an emerging technology of information. While Foucault's writings were most directly concerned with the rise of modern statecraft in Western Europe, it is the central idea of this paper that the notion of information-based governmentality is also crucial to an understanding of developing and emerging societies. In what follows, I offer a genealogy of information and statehood in India by examining how information as a category was brought into play in successive stages of contemporary Indian history. The entire "modern" era, I suggest, is one in which information is a key constituent of state formation, national identity and political philosophy. I begin the paper with a discussion of the Aadhaar card, a contemporary attempt to uniquely identify every citizen of the country by means of an informational device. This first section provides a broad account of the creation of the Aadhaar card and briefly reviews the controversies it has generated. The purpose of this exercise is not to provide a comprehensive or definitive account of all the issues at stake here, but rather to highlight the fact that in this "informational age" it is impossible to think the notion of citizenship without its informational correlates. It would be wrong, however, to conclude that such a perspective is entirely novel. In the next three sections of the paper, I try to provide historical snapshots that illustrate information's constitutive role in previous versions of the Indian state. The second section looks at the role information played in British India and suggests that data collection and management was crucial to the colonial government as a means of apprehending and ruling its subjects. The third section examines the nationalist phase in pre-independence India 
and proposes that information animates the freedom struggle by functioning as speculative category that dreams and thinks the nation. In other words, if the colonial powers continuously "mined" information for their mission of imperial rule, facts and figures would be equally valuable in allowing nationalism to conceptualize what the future free India would approximate to. The fourth section looks at the preliberalization period of postcolonial history to trace how information becomes a state "good" that is both strictly controlled and sparsely disseminated while at the same time acting as a spur to a specialized sort of economic activity. In short, between 1947 and 1991, information becomes subsumed under the aegis of statist development. Finally, in the fifth and concluding section of the paper, I revisit the implications of the Aadhaar card in particular and of informational governance in general, by placing both in the context of contemporary political and administrative developments.

2 A note on methodology: this paper is an interpretive exercise that attempts to elucidate the various meanings and uses of information over a broad sweep of Indian history. It is based less on primary research than on an analysis of broad trends of governmental practices and discourses that describe and categorize different stages of informational statecraft. This analysis is based on academic scholarship on the topic as well as on journalistic reports and commentaries. The paper's contribution lies, I hope, in coming up with a theoretical framework that helps us better understand the central role played by information in enabling successive moments of the Indian state-the colonial regime, the nationalist movement, the postcolonial period, and the new millennium. The account I provide is more genealogy than history in the sense that I don't provide a single narrative that seamlessly recounts the development of the idea of information, but rather demonstrate the specific forms of conjunction between information and governmentality that are generated in particular social moments or spaces. My analysis is based on four guiding metaphors which I believe succinctly capture the central role that information plays in the operations of the social forms I am looking at: the colonial social formation was characterized by information as extrapolation; for the nationalist movement information functioned as imagination; in the postcolonial period information was equivalent to domination; and finally, in the age of Aadhaar information is societal.

\section{Founding Aadhaar}

The informational impulse behind the philosophy of governance in contemporary India is most strikingly illustrated by the Aadhaar card, a document bearing a unique identification number for every resident of the country. Aadhaar-the word means "foundation" in many Indian languages-is a biometric device that links each individual's identification number to their fingerprints and to their iris scan. Launched in 2009, the Aadhaar initiative has, according to official claims, enrolled 1.2 billion individuals in the space of a few years. Even if this figure is not wholly accurate, this effort is a remarkable achievement given the size and complexity of its constituency. The creation of the Aadhaar project underlines the Indian state's turn to an informational model of society and its firm resolve to use digital technology in the interests of governance. While such a shift has become highly evident in this new millennium, this paper will argue that the fusion of information and statecraft has a long history that spans both the colonial and postcolonial periods. 
The roots of the Aadhaar card lie in anxieties concerning national security. After the 1999 Kargil War with Pakistan, a review committee headed by the noted defense expert K. Subrahmanyam recommended that villagers living in border areas be provided with an identity card to ensure greater security. The idea was strongly endorsed by the Bharatiya Janata Party (BJP) government then in power, which announced that it would soon create a "multi-purpose national identity card" to be issued first to villagers living near the border with Pakistan and then to others as well. The BJP government was voted out of power in 2004 and succeeded by a less overtly paranoid coalition led by the Congress party, but the idea of an informational tool that would identify the entire citizenry of the nation did not die. The rationale for such an initiative had however changed. As the founding document of the Unique Identification Authority of India put it, "In India, an inability to prove identity is one of the biggest barriers preventing the poor from accessing benefits and subsidies. Public as well as private sector agencies across the country typically require proof of identity before providing individuals with services. But to date, there remains no nationally accepted, verified identity number that both residents and agencies can use with "ease and confidence." (UIDAI 2009) In other words, a unique identity card for every resident in the country was required not because it would prevent illegal infiltration across the country's borders, but because it would enable efficient delivery of welfare services. Thus was born "AADHAAR," a unique identity number, "through which the citizen can claim his/her rights and entitlements when assured of equal opportunities, as symbolized by the logo, which has the halo of the Sun on the imprint of a thumb" (Balchand 2010).

There was considerable truth in the assertion that India lacked an identity system that would facilitate the disbursement of welfare goods and services. Thus in 2008, a year before Aadhaar was launched, only 40 million Indians possessed passports. The corresponding figures for the PAN card (Permanent Account Number), ration card and voter ID card were 70 million, 220 million and 500 million respectively (Reach Project 2017). The identity system was not only fractured, it was also dysfunctional in the sense that forms of proof that were widely accepted (passports, PAN) were held by very few, while those held by many-ration cards, NREGA (National Rural Employment Guarantee Act) cards and voter ID cards-were of limited utility. For example, many individuals were unable to use these cards outside of the state in which they were issued. Moreover, both ration cards and NREGA cards were issued to families rather than individuals, thus making access to these documents very contingent. As the document laying out the justification for Aadhaar project pointed out, the consolidation of various forms of identity into one single instrument would have manifold benefits: 
There are clearly, immense benefits from a mechanism that uniquely identifies a person, and ensures instant identity verification. The need to prove identity only once will bring down transaction costs for the poor. A clear identity number would also transform the delivery of social welfare programs by making them more inclusive of communities now cut off from such benefits due to their lack of identification. It would enable the government to shift from indirect to direct benefits, and help verify whether the intended beneficiaries actually receive funds/subsidies. A single, universal identity number will also be transformational in eliminating fraud and duplicate identities, since individuals will no longer be able to represent themselves differently to different agencies. This will result in significant savings to the state exchequer (UIDAI 2009:1).

6 The intention to create a unitary identity system that would be pro-poor made sense in an environment where roughly 70 percent of the population lived in rural areas and 270 million Indians, roughly one in five, were poor according to World Bank measures. Further, approximately 400 million of India's workforce are internal migrants (Reach Project 2017). Once migrants move from their original place of domicile, it becomes hard for them to obtain identificatory documents that would enable them to obtain government services. This migrant population would benefit immensely from a standardized document that would enable them to access a whole range of services and resources. An additional advantage of Aadhaar comes from linkages that can be established between the UID and other governmental instruments thus expediting the disbursements of due benefits. Take the case of NREGA, the social program that guarantees rural households a minimum amount of paid work. In Vijayawada, Andhra Pradesh, the delivery of NREGA wages used to take 20 to 30 days to reach a household. Government officials in Andhra Pradesh have found that since individuals have been able to link NREGA to their Aadhaar number, those same wages are now delivered in three to four days (Reach Project 2017). At the same time, the card would benefit private industry by helping to create a smoother environment for capital. Nandan Nilekani, the software leader who was appointed as the first Chairman of the UIDAI, argued that Aadhaar would enable the average citizen to open a bank account in a smooth and quick manner thus building a bridge between capital and citizenry. As Visa card's Uttam Nayak stated, "If 600 million Aadhaar holders get bank accounts India can leapfrog from a banking penetration of 24 per cent to the 75 percent common in developed countries like the US. Simultaneously, we can go from 3 percent 'electronification' to 40-50 percent. That is unprecedented in the world" (Dharmakumar 2013). The case for the Aadhaar card was perhaps most succinctly made by the founding UIDAI document: "India will be the first country to implement a biometric-based unique ID system for its residents on such a large scale. The UID will serve as a universal proof of identity, allowing residents to prove their credentials anywhere in the country. It will give the government a clear view of India's population, enabling it to target and deliver services effectively, achieve greater returns on social investments, and track money and resource flows across the country" (UIDAI 2009).

7 Aadhaar is not without its vociferous critics. Nikhil Dey, a prominent social activist described the UDI as, "the opposite of RTI [Right to Information]. We fought all these years to have government information made public; and now the government will have access to every act of every citizen and it'll be kept secret", while another activist, Usha Ramanathan, alleges that, "such initiatives exemplify how the Indian state is currently 
collecting biometric data from citizens without a law, simply because no one is stopping them" (Dharmakumar et al 2013).Again, other RTI activists like Shailesh Gandhi worry that the Aadhaar project directly hurts the principles and practices of the Right to Information Act (Gandhi 2017). Several commentators have pointed out the potential anti-democratic consequences of a unique identity system. For example, Basil Mathew (2014) observes that India has launched many projects like the Criminal Tracking Network and Systems (CTNS), the National Counter Terrorism Centre (NCTC) and the Central Monitoring System (CMS), all of which were established unilaterally without the permission of Parliament and constitute serious intrusions into the privacy of citizens. Mathew also points out that in this neoliberal era, the linking of Aadhaar with private entities constitutes a grave risk of malpractice with data collected for the purposes of UID leaking out into other hands. In her study of the social life of UID amongst Delhi's homeless population, Ursula Rao argues that rather than profiting from these new technologies, the homeless suffered from their implementation. They were often handicapped by not having a permanent address, and very often their bodies were "unreadable" by the machinery of identification. In many cases, the thumbs of the poor and the aged would not yield a thumbprint, a must for the Aadhaar card. Rao (2013) argues that biometrics is not a neutral technology, but an emerging technique that "forms at the conjunction between machines, biological bodies, social habits, and their contexts" (p. 73). Thus, UID is to be seen as a normalizing technology that "reads and integrates individuals [who are] sufficiently adjusted to a mainstream social and biological body" (Rao 2013:77).

8 Aadhaar's most vocal and persistent critic, Usha Ramanathan (2019), has observed that "The age of mass surveillance is upon us." Ramanathan points to the fact that the Home Ministry has deemed that any information generated, transmitted, received or stored in any computer resource is of interest to the state. Even more sinisterly, the Indian government has been conducting secret meetings with representatives of technology companies like Facebook, Google and Amazon, whose use of data goes well beyond the needs of advertising, and often includes shady linkages with military and defense establishments. It is with these companies that the Indian government is in discussion on how to surveil the people of this country. The UID project involves the sharing of biometric data with companies such as L-1 Solutions which have close links to the CIA. Equally disturbing is the government's decision to set up a technology platform to collect digital chatter in order to create a 360-that is, total-profile of all individuals who can be classified as internet influencers. UID then is not just a tool for convenient governance. The manner in which it is used has to do "with the future of freedom itself" (Ramanathan 2019).

9 It is not the purpose of this paper to adjudicate between competing evaluations of the Aadhaar initiative. What needs to be noted is UID's universal appeal at the governmental level-it was first conceived of in the aftermath of the Kargil war by the BJP leadership as early as 1999 , established by the Congress-led UPA government in 2009 , and fully implemented by the BJP government that came to power in 2014. Today, under the re-elected leadership of Narendra Modi, Aadhaar is an established feature of the bureaucratic landscape. The only debates surrounding it pertain to the card's limits: that is, to what extent the card is necessary for the transaction of services and business. Thus, in September of 2018, the Indian Supreme Court ruled that Aadhaar is constitutional in the sense that it does not violate an individual's right to privacy when that individual agrees to share biometric data. It further ruled that Aadhaar is 
mandatory for filing income taxes or for obtaining a PAN (permanent account number). On the other hand, it struck down Article 57 of the Aadhaar Act, as a consequence of which no private company or entity can seek an Aadhaar card number from any individual for the purpose of doing business (liveMint 2018).

The Aadhaar card is here to stay and that is because the Indian state, as it exists now, is an entity characterized by a strong commitment to the complete integration of information technology and governmental practices. From the perspective of this paper, the Aadhaar project symbolizes the fourth of my guiding metaphors for conceptualizing such a relationship-information as societal. In this latest iteration, the concept of information is deemed to be foundational to the very formation of society itself, an idea that I will explore a little more thoroughly in the concluding part of the paper.

\section{Information in the Colonial Regime}

11 In the autumn of 1858 , a young British civil servant named William Herschel, serving at the time in the north Bengal district of Maldah, entered into a contract for the supply of road-making material with a local businessman called Rajyadhar Konai. As Konai was preparing to sign the contractual document in the traditional way-in the upper right hand corner-Herschel, who had come to "distrust all evidence tendered in Court" and had come to "despair of any good coming from orders and decisions based on such slippery facts", decided on a sudden impulse to ask the contractor to stamp the contract with a print of his right hand (Sengoopta 2003:57). Thus was born the idea of the fingerprint, an impression that recorded an individual in the form of unvarying ridge-pattern data taken from the finger. A successor of Hershcel's, Edward Henry, further developed Herschel's revolutionary procedure, and in 1897 announced a system of fingerprint classification that "the greatest sceptic would be at once convinced of identity on being shown the original and duplicate impressions" (Sengoopta 2003:139). The Bengal system of fingerprinting soon spread all over British India and then back "home" in England, as well as in the rest of the English-speaking world.

The introduction of fingerprinting-still a crucial part of the Aadhaar card's "operating system"-as a standard mode of bureaucratic governance points to the crucial role that was played by information in the constitution of the colonial state. As numerous scholars have demonstrated, the entire colonial period was marked by a series of efforts at generating information that would produce a comprehensive "knowledge" of the territory and its peoples. The entire history of colonialism is dotted with such epistemological projects: narratives of the conquered nation written by such notable authors as Alexander Dow (1772; An Enquiry into the State of Bengal), James Mill (1817; The History of British India) ${ }^{1}$ and James Tod (1832; Annals and Antiquities of Rajast'han); surveys of the land conducted by geographers like William Lambton (1802; The Great Trigonometric Survey) and James Rennell (1779; Bengal Atlas) Colin Mckenzie (1799; Mysore Survey) and Frances Buchanan; the recovery and recodification of native language, literature, law and lore compiled by Orientalists like Thomas Munro, William Jones (1796; Institutes of Hindu Law) and N.B. Halhed (1776; A Code of Gentoo Laws ). What lay behind this unbounded thirst for information? In the words of one distinguished commentator, such enterprises were undertaken in order "to enable the British to 
classify, categorize, and bound the vast social world that was India so it could be controlled" (Cohn 1996:4-5).

Such an observation stems from a distinctive historiography of colonialism. If traditional Marxist scholarship analyzed colonialism as a unique mode of production that arises in "the last stage of capitalism"2 Michel Foucault's distinctive account of modernity allows us to read colonialism not only in economic terms, but also as a mode of governance that imposes knowledge, precepts and rules upon a subject population in order to make the colonial project viable. In a well-known essay, the anthropologist David Scott (1995) has argued that we attend to the "political rationalities of colonial power" that "characterize those ways in which colonial power is organized as an activity designed to produce effects of rule" (p.193). Following Foucault's (2001) observation that "Maybe what is really important for our modernity-that is for our present-is not so much the statization [etatisation] of society, as the "governmentalization" of the state" (p.220), Scott (1995) rethinks colonialism in terms of a "colonial governmentality" that sets up the very terms and logic of societal discourse "so as to produce not so much extractive-effects on colonial bodies as governing-effects on colonial conduct" (p.204).

The notion of colonial governmentality is indispensable for a full understanding of colonialism. If governmentality was the defining feature of the modern European state, it had an even stronger salience in the colonial context. Imposed by military methods on an alien population, and dedicated to crude extraction and unfair imperial trade, the colonial state could scarcely turn to notions of sovereignty and the natural order as the basis for its rule. Its hold and legitimacy could therefore only be established by reorganizing its human territory by means of the conceptual apparatus and strategic tactics that embodied the guiding ideas and principles of western modernity. In other words, the constitutive logic of the colonial state implied that it was "governmental" from the very moment of its inception. Consequently, the Indian colonial state, first as Company Bahadur and then as the British Raj, could sustain itself and evolve by expanding the scope of this governmentality. One can map this endeavor, as Scott (1995) suggests, by looking at the targets of colonial power-where it was applied and the means and instrumentalities deployed-as well as the field of its operation-or as Scott puts it the "zone" it constructs for its functionality (p.193). In other words, colonial power is used not only at the levels of material goods and human population, but in a discursive zone as well, since the exercise of colonial governmentality depended crucially on a ceaseless process of information gathering, information processing, and information distribution. There is by now a vast amount of literaturein fields such as historiography, social statistics, mapping, legal studies, literary studies and aesthetics-that critically examines this process as it unfolded and that ably demonstrates the creation of a "discourse" that provided the cognitive underpinning for colonialism as a political and economic phenomenon. To sum up, the colonial regime needed information as a means of governance of its body of subjects. The gap between the colonizer and colonized, called for a specific mode of knowledge (of which anthropology is a prime example) that maintained difference while facilitating a very specific mode of domination. Whereas Aadhaar collects biometric information in order to essentially define and capture the "citizen," the colonial drive for information is vaster in its scope; it seeks to know "everything" about its subjects if only because it fears them to be unknowable. 


\section{Information and Nationalist Thought}

15 challenges the moral authority of colonial rule, argues for self-rule, launches freedom struggles and eventually succeeds in transforming the colonial state into a free postcolonial nation. I would like to suggest that nationalism is also an epistemological project; one that redefines what can or should be known in order to establish a legitimate nation. Nationalist thought is an exercise in virtuality; it uses information to imagine a nation that would come to fruition at the moment of independence. Virtual nationalism dwelt in the realm of the potential, and expressed itself through a series of blueprints, projections, resolves and resolutions that calculated and calibrated what was yet to be. Planning, understood as "informed futurity", that is, an activity that imagines the future on the basis of information regarding the present was the manifest form of virtual nationalism as it has just been defined. Not surprisingly then, planning played an important role in the nationalist movement, and was to play an even more significant role in the destiny of postcolonial India.

The years immediately before 1947 saw a succession of "plans" that were blueprints for developing the independent nation that was already visible on the horizon. The Resolution of Fundamental Rights and Economic Programme passed at the Karachi Congress held in 1931 is perhaps the very first document of this sort. Though not technically a "plan," the sentiments expressed in the Resolution certainly assumed state planning as the fundamental component of the future economy. Thus, it declared that in the age of Swaraj, "the State shall provide free and compulsory education... safeguard the interests of industrial workers...protect indigenous industries" and "shall own or control key industries and services, mineral resources, railways, waterways, shipping and other means of public transport" (National Planning Committee 1988:3133) The Karachi Resolution presaged a flood of similar publications: In 1934, the noted economist Sir M. M. Visvesvarya published his Planned Economy for India, followed in 1935 by N.S. Subba Rao's Some Aspects of Economic Planning. At the behest of its President Netaji Subhas Chandra Bose, the Congress party constituted a National Planning Committee under the chairmanship of Jawaharlal Nehru. The Committee, formed in 1938, would release several reports in the next few years, many authored by Nehru himself. In 1944 a group of industrialists that included two of India's most famous business leaders-J.R. D. Tata and G.D. Birla-released "The 'Bombay' Plan for India's Economic Development." The same year also saw the publication of a "People's Plan" authored by the radical humanist and ex-communist M.N. Roy on behalf of the Indian Federation of Labour. In 1945, the government of India issued two documents-the "Second Report on Reconstruction Planning" and the "Industrial Policy Statement"both of which outlined a vision for post-war India. Finally, a "Gandhian Plan" for India (1949), written by S.N. Aggarwal, was the last such anticipatory document to come out before planning became a reality in the early fifties with the establishment of the Planning Commission and the launching of the First Five Year Plan.

These proposals represented very different constituencies of the emerging nation and one would expect them to have widely divergent prescriptions for development and growth. But in spite of these differences, all these plans shared a common vision. In his analysis of the national postcolonial state, the eminent postcolonial theorist Partha

South Asia Multidisciplinary Academic Journal, 23 | 2020 
Chatterjee (1993) points out that planning appeared first and foremost as a form of determining state policy. Executed by "experts," planning "emerged as a crucial instrumental modality by which the state would determine the material allocation of productive resources within the nation: a modality of political power constituted outside the immediate political power itself." What this implies is that "a developmental ideology...was a constituent part of the self-definition of the postcolonial ideology" (pp.202-203). ${ }^{3}$ I would supplement Chatterjee's observations by pointing out that while planning is clearly the key instrument for a "developmental ideology" it is at the same time the ground for the emergence of an informational order. Consider the following definition of planning put forward by a sub-committee of the National Planning Committee:

\begin{abstract}
What is planning? Planning under a democratic system may be defined as the technical co-ordination, by disinterested experts, of consumption, production, investment, trade and income distribution in accordance with social objectives set by bodies representative of the nation. Such planning is not only to be considered from the point of view of economics and the raising of the standard of living, but must include cultural and spiritual values and the human side of life (National Planning Committee 1988:51).
\end{abstract}

Defining planning as an activity consisting of "technical co-ordination, by disinterested experts" may be indicative of the emergent middle-class "bourgeois" ideology that would come to dominate Nehruvian India; but at the same time such a vision unleashes an informational program that comes to strongly influence and characterize the nature of the postcolonial formation. In other words, the idea of planning is inconceivable without the idea of information, and at the same time the project of planning would, as I discuss in the next section, be directly responsible for India's information revolution.

Most of the notable nationalist leaders were wholeheartedly committed to the idea of planning. Jawaharlal Nehru, the face of Indian politics after Gandhi, was the central figure in this respect. In a note directed at his fellow member on the National Planning Committee he wrote:

To realize the social objectives, the state has to plan through its representatives...This planning will deal with production, distribution, consumption, investment, trade, income, social services and the many other forms of national activity which act and react on each other. Briefly put, planning aims at the raising of the material and cultural standard of living of the people as a whole (Gopal 1980:306).

In other words, Nehru was calling for a great informational exercise that would cognize every realm of the economy and society in order to predict and produce the India that was to come. Such a stance was not restricted to Nehru; his great rival in the Congress party, Subhas Bose, announced that "when we have a national government for the whole country, one of the first things we shall have to do is to appoint a National Planning Commission for the whole country" (Bose 1962:54). This rhetoric is unchanged almost a hundred years later-the Aadhaar card according to an advisory committee set up at the time of its launch is characterized by an "anytime, anywhere, anyhow" authentication ability that "will provide the user universality of usage across service providers, across the country" (Aadhaar, Communicating to a Billion, 2010). For the pre-Independence Congress party and the Aadhaar Advisory Committee alike, 
information gathering and management are the key to economic development and to social progress.

19 I want to conclude this section by considering the case of P.C. Mahalanobis, the principal architect of the Second Five-Year Plan (1951-1961) and perhaps the single most influential figure in the history of Indian economic planning. Mahalanobis was a statistician of international repute and had been responsible for the founding of the Indian Statistical Institute in 1932, as well as the reputed statistical journal Samkhya, which was founded in 1933. Like Bose and Nehru, Mahalanobis was yet another key mid-century figure who believed in the essential unity of science and planning. For him statistics was "essentially an applied science" that's "aim is to reach a decision, on a probabilistic basis, on available evidence" (Mahalanobis 1950:210). This applied science was therefore at the very heart of planning. In an address to the American Statistical Association, Mahalanobis drew attention to the governmental benefits of statistics: "It had its origin in the counting of men or cattle...the very word statistics shows its connection with 'statecraft'." In as much "It is essential, in underdeveloped countries to make statistics purposive" (Mahalanobis 1965:45-46). Not only did Mahalanobis found the discipline of statistics in India, in his later role as the chief architect of the Second Five Year Plan he was instrumental in setting the tone of India's policy-making for the next three decades. The primary objective of the Plan was to raise the level of living in the country by means of "rapid industrialization with particular emphasis on the development of basic and heavy industries" (Second Five Year Plan). The bias toward technology would become evident in the push for developing industries like coal, electricity, iron and steel, and chemicals. There was early recognition on the part of Mahalanobis and others that information technology was a resource as important as any of the "heavy" industries. Thus, the Indian Statistical Institute (ISI), under Mahalanobis, built the country's first analog computer in the early 1950s. ${ }^{4}$ Recognizing the need for more advanced technology, Mahalanobis formed a small computer group at the ISI and ordered a computer from the British Tabulating Machines (BTM) which was at the time marketing keypunch machines, sorters and mechanical calculators in India. BTM agreed to sell a computer to the ISI in 1954, though without any technical support. The ISI was to install and maintain the machine using its own scientists and engineers. The ISI sent two of its scientists to England to learn the basics of this HEC2M (Hollerith Electronic Computer Model 2M) computer. The computer arrived in Kolkata in July 1955 and it started working in August 1955 (Rajaraman 2012). Mahalanobis was a key figure in that he forged the path between a mathematical approach to information processing and a computational one. Along with Bose and Nehru he represents that strain of nationalism for which information gathering and processing is an integral part of creating a nation.

\section{Information in the Post-Colonial State}

In this section, I examine the role that information played in the years after Independence as the Indian state sought to define and develop a just-born nation. This postcolonial period was characterized by two developments. ${ }^{5}$ The first was a possessive attitude and a consequential safeguarding of information relating to matters of state. This led to a practice of hoarding and locking up information and disseminating it in small doses, often in the shape of propaganda. Secondly, the Indian government began 
to acknowledge the growing role information and information technology was beginning to play in the global economy and started taking discreet measures that would enable Indian industry to master and then generate revenue in this sector.

The nature of the Indian social formation in the period 1947-1991 determined the state's stance towards communication and information. First, the Indian state was firmly committed to a socialist path to development. This meant that the state retained ownership of crucial capital-intensive sectors like oil, steel, railways, defense equipment and so on. In particular, the state assumed control over both broadcasting and telecommunications, including telephony. For example, not only were telephone lines and exchanges under governmental control, but, the handsets themselves were manufactured by a public sector company. Secondly, a paternalistic attitude towards the masses-derived partly from colonial antecedents and partly from still prevalent feudal hierarchies of caste, class and status-meant that communication and information were thought of as the exclusive property of the state, to be disseminated in a manner that could only be determined by officialdom. Thirdly, the developmental bias of this period meant that attitudes towards communication and information were marked by extreme frugality. Thus Nehru-whose personal whimsy often translated into national policy-saw television as a luxury meant only for the affluent and thus did little to encourage its growth (Majumdar and Mehta 2012). As a result, television was inordinately late coming to India, and even during the first two decades after it was introduced in 1969, television broadcasting remained both skeletal and rudimentary.

The notion that information and communication needed be under the purview of the state has a long history in the Indian context. As the famous Indian Telegraph Act of 1885 announced quite unequivocally, "Within [India] the Central Government shall have the exclusive privilege of establishing, maintaining and working telegraphs" (The Indian Telegraph Act 1885:36). The scope of the government's involvement with information and communication was necessarily enlarged with the advent of radio broadcasting. Although the very first radio broadcasts (1927) in India were made by the privately-owned Indian Broadcasting Company, the venture failed and the colonial government took over the role of broadcasting with the formation of the Indian Broadcasting Service in 1932. The IBS was renamed All India Radio (1936) and was then placed under a separate Ministry of Information and Broadcasting. In short, both interpersonal communication (by means of post, telegraph and telephone) as well as mass communications (radio, television) were thought of as informational domains that need to be subsumed within the state; either by state ownership of channels of distribution as in the case of the post, telegraph or telephone, or by control over both content and channel in the case of radio and television. In spite of two notable exceptions-the press and the Bollywood film industry which were both privately financed and subject to the mildest of censorship-it is still legitimate to describe this period as one in which information (and its communication) was thought of primarily in statist terms.

23 To sum up, in the period 1947-1991, the Indian state's relationship to information was highly proprietary. Such a top-down informational paradigm can be dubbed as "premodern" in the sense that it did not promote, and often actively blocked, the continuous flow of information between private entities that was characteristic of all advanced capitalist societies. Even while the Indian state strictly controlled both the 
production and distribution of information, it would also begin to embrace the idea of the information age.

India's entry into the digital era can be said to have begun in January of 1962, when the Prime Minister of India, Jawaharlal Nehru, inaugurated the TIFRAC, an indigenously manufactured first-generation mainframe computer that was meant to boost the nation's scientific capabilities (Deccan Herald 2010). Named after the prestigious research institution in which it was housed, the Tata Institute of Fundamental Research Automatic Calculator, which had been many years in the making, would remain in operation for a mere two years. Its impact on Indian society, however, was incalculable insofar as it announced the dawning of a new era that would be based on information. In the immediate aftermath of Independence, state economy policy was heavily biased in favor of domestic industry. At the same time, however, the Indian state's relationship with global capital was far less amicable. Thus, the Industrial Policy Resolution of 1948, that set the tone for the country's financial philosophy, held that foreign investment had to be carefully regulated in the national interest and that "majority interest in ownership and effective control should always be in Indian hands" (p. 95) In other words, the postcolonial state's stance towards capital in general was both complex and contradictory: abetting and colluding with domestic capital on the one hand, and hostile and intransigent to global capital on the other.

An analysis of India's information sector in the Nehruvian period complicates this tidy dichotomy. As even a cursory glance at the development of the computer industry will show, contrary to the received wisdom, the postcolonial state was establishing ties with global capital even at the height of the autarkic period. The post TIFRAC period is marked by successive events that demonstrate how the digital domain provides a site for the postcolonial state's increasing engagement with global capital: the allowing of software export, the relaxation of import restrictions, the creation of Special Economic Zones (SEZ), the institution of body shopping, the opening of doors for foreign multinationals, and finally the wholesale integration of the software industry into the global marketplace. In short, the saga of the information sector in Nehruvian postcolonial India both enacts and predicts the large-scale changes brought about by liberalization.

The trajectory of the computer industry in the period 1967-1978 can be seen as an ambiguous period in which the principles of Nehruvian postcoloniality were being both strengthened and diluted at the same time. The establishment of the Electronics Commission of India Limited (ECIL, est. 1970), an organization whose goal was to develop an indigenous computer industry, as well as the passage of strict foreign exchange laws that limited the amount of external capital that would be allowed into the country FERA were in keeping with the state's avowed mission to create a selfsufficient society based on socialistic principles. At the same time, however, there was a realization that these very principles had to be compromised if India was to earn the revenue needed to address its balance of payment problems. The most interesting development in this regard was the setting up of export processing zones (EPZ) that would not be subject to the usual tariffs and duties levied on any sort of international trade. The first such EPZ was opened in 1965 in Kandla, a port town in the state of Gujarat. However, it is the Santa Cruz Electronics Export Processing Zone (SEEPZ), located in Andheri East, Mumbai, which is of more relevance to this present discussion. SEEPZ was set up in 1973 as single-product Export Processing Zone that would 
exclusively manufacture and export electronic items, with the objective "of (a) accelerating the progress of electronics manufacturing in India and (b) to take advantage of the growing electronics world market" (Special Economic Zone 2015).

The SEEPZ scheme would be a small but promising way to step up the export sector. The announcement of the scheme had the effect of enticing the giant US company Burroughs, which then ranked amongst the top 10 computer companies in the world, to enter India and set up a joint venture with the fledgling Tata Consulting Services. The collaboration with Burroughs gave India's software professionals an intimate knowledge of global business practices and would thus serve as a springboard for the growth of the entire software industry. In the words of one commentator, "The Indian software saga...began in SEEPZ Mumbai" (Aggarwal 2006:4533).

The Export Processing Zone model gave birth to the phenomenon known, somewhat notoriously, as "bodyshopping", which involved the practice of sending software personnel to the US, UK and other countries to work at onsite on temporary projects. Bodyshopping dominated the industry in the 1980s, but would soon be replaced by offshoring-the implementation of IT services, Business Process Outsourcing (BPO), Software Products and Engineering services from within India would soon become the main engine for the remarkable growth of the Indian industry. Buoyed by the revenues generated by offshoring (also known as outsourcing), Indian software exports increased from EUR 5.93 billion in 2003-2004 to EUR 20.20 billion in 2008-2009, and the industry saw an astonishing growth rate of almost 25 percent (Malik 2011).

I want to end this section by briefly mentioning two state initiatives-the New Computer and Software Policies of 1984 and 1986, and the decision to set up of software technology parks (STPs) in 1990-that further confirm the thesis that the information sector was the site where the state "rehearsed" its turn to the free market before the liberalization of 1991 . The opening up of the computer industry would be accelerated by the passage of two policy enactments: The New Computer Policy (NCP) of 1984 and a policy on software export passed in 1986. The NCP employed a strategy of "flood in, flood out" (Subramanium 2006:380)-flood the nation with imports and cause a larger flood of software exports-and eased the availability of computers in India by reducing the software import tariffs from 100 percent to 60 percent. Within a year of its implementation, computer production grew by 100 percent, while prices fell by 50 percent. Software exports too began to increase, and recognizing its huge potential, the government also introduced a policy on computer software export, development and training, the objective of which was to "promote software exports to take a quantum jump and capture a sizable share in the international market" (Sharma 2009:140).

The last development of note that occurred in the computer/software industry before liberalization was the establishment of Software Technology Parks, which were dutyfree privately managed enterprises that could attract investments and boost exports in the software industry. The first STPs were established in Bangalore, Pune and Bhubenswar in 1990 and within two decades there were as many as 47 such centers operating across the country (Vaidyanathan 2008:288). As the noted economist Pulapre Balakrishnan (2006) has observed, STPs "were to radically transform the environment for software production in India and thus the Indian IT industry. The STP, by providing an exclusive state-of-the-art physical site for software production, especially access to high-speed communication channels, enabled the Indian IT industry to sidestep the infra-structure constraint that is stoically faced by the rest of India's manufacturing 
sector...The rise of the offshore model reflected the rising confidence in the Indian software firm worldwide" (p.3869).

31 There is a common thread running through the establishment of Special Economic Zones, the passage of the minicomputer and New Computer policies, and the introduction of Software Technology Parks. All these instances collectively symbolize the information sector's unique role in mediating the relationship between the postcolonial state and capitalist democracy. Information stood at the fault line between two drives, one demanding that the country be dedicated to a socialist path that would make the nation autonomous with regard to the world capitalist order, and a second that called for the adoption of current technological goods and practices in order to steer the nation into modernity. The second tendency would eventually win out, and the postcolonial state's gradual acknowledgement that information was an economic "good" had the effect of loosening its proprietary stance. This would, in no small measure prepare the way for economic liberalization and the beginning of the current era of informational governance.

\section{Conclusion}

As the discussion above has demonstrated, the relationship between information and the state in India has gone through four distinct stages. Under British colonial rule, information was continuously extracted from the populace, much in the same way as raw materials and other resources, in order to properly cognize the body politic in the interests of imperial rule and hopefully turn the population into loyal subjects. For the nationalist movement that arose at the end of the nineteenth century, information was an equally prized object, but its role was quite different. Information would help to dream and plan the nation that was incoming, it was therefore the means to visualize the citizen of tomorrow in a free India. With Independence, information became the property of the State, its possession and distribution becoming a matter of great national importance. Concurrently however, the new information order dissolved the State's commitment to autarky and helped to integrate India into the new global economy that was beginning to take place. The present situation is one in which the primacy of information in the realm of both economics and governance are taken for granted. As Manuel Castells (2009) has argued in his seminal writings on the topic, "Informationalism is the technological paradigm that constitutes the material basis of early $21^{\text {st }}$ century societies" (p.9). The Aadhaar card project weaves together the new conceptions of state, citizenship, information and governance that characterize contemporary Indian politics.

33 We can achieve a fuller and deeper understanding of this philosophical and political paradigm by placing the Aadhaar project alongside similar initiatives like the National Register of Citizens (NRC). The NRC is, in the words of the Office of the Registrar General \& Census Commissioner, India (2019) "a register of usual residents of the country" whose objective is to provide a comprehensive database of every resident using demographic and biometric particulars. The creation of the NRC was mandated by the Citizenship Act of 1955 (and by its 2003 amendment) but the initiative was not implemented anywhere until under a Supreme Court order of 2013, the state of Assam was asked to compile such a register. The final list of the state's 33 million inhabitants was released in August 2019, with nearly 2 million residents having failed to make the 
list. Two crucial observations must be made here. First, the central idea behind the NRC -that every citizen of the nation needs to be enumerated and inscribed-is the same one that animates the Aadhaar project. Taken together, the two projects embody the belief that information is societal, meaning not only that society is to be founded on a bedrock of data but also that social being can only be enacted through informational devices and processes. Thus, if the NRC provides a "base of data" upon which the nation stands, the Aadhaar card symbolizes how day to day transactional life is possible only with the employment of informational tools.

Secondly, the NRC (and its adjunct, the recently passed Citizenship Amendment Act or CAA) is a striking illustration of how an abstract informational philosophy of citizenship can be put to use in the context of identity politics. Even though the idea of a national register of citizens was implicit in all pronouncements about Indian citizenship, the only time an actual register was created was immediately after the 1951 census. Quite remarkably, between that year and the release of an NCR report in the state of Assam in August 2019, there was no attempt to revive the idea of an NCR. The Indian state was quite content, it appears, to rule and govern, without any explicit knowledge of its subjects. It is only in the aftermath of the Aadhaar initiative that the NRC would be revived for one singular case-Assam. Ever since the province of Assam was created in the years following the Mutiny it has been a contested terrain in terms of identity and ethnic politics (Chakravarti 2019). One major source of conflict was migration from neighboring areas, an issue which resulted in the Assam Movement of 1979 demanding expulsion of "illegals." It is therefore no coincidence that in the desecularized climate of the new millennium the Supreme Court of India responded to two writ petitions filed by non-governmental organizations from Assam and ordered the state and central governments to update the NRC in accordance with the Citizenship Act of 1955 and the (amended) Citizenship Rules of 2003. The court's intent here was to ensure that such "illegals", many of whom came from the minority community, would both be identified and lose their legitimacy as denizens of the land. As Ranjit Samaddar (2018) aptly observes, "Citizenship and statelessness have never been so linked as they are today." After two rounds of publication of drafts of the register, a partial one on December 31, 2017 and a final draft on July 30, 2018, the final list was published on August 31, 2019, with 1.9 million inhabitants of the state being found wanting with valid documentation required to establish their identities. (Barbora 2019). Given that half of this undocumented population turned out to be Hindus, the BJP government reacted rapidly by passing the Citizenship Amendment Act that granted legal status to members of the Hindu, Sikh, Jain, Parsi or Christian community from the three neighboring countries of Bangladesh, Pakistan and Afghanistan who had sought refuge in India. At the time of writing, India is being convulsed by massive protests against the CAA that have elicited a very brutal response from the current government in a striking proof of the proposition that information can get entangled with the most uncivil forms of political conflicts. Designed to account for every citizen of India and to provide each constituent of the nation with a unique biometric profile, projects like the Aadhaar card and the NCR offer a new foundation for citizenship. Though it is beyond the scope of this paper, such schemes represent the convergence between state and capital to reassemble governance around notions of access, information, and digital consumerism. In other words, the present moment is witnessing a push to construct a new citizen-subject who will function as a node within an emergent ecology of information. 


\section{BIBLIOGRAPHY}

Aggarwal, Aradhna. 2006. "Special Economic Zones: Revisiting the Policy Debates." Economic and Political Weekly 41(43/44):4533-6.

Balakrishnan, Pulapre. 2006. "Benign Neglect or Strategic Intent? Contested Lineage of Indian Software Industry." Economic and Political Weekly 41(36):3865-72.

Balchand, K. 2010. “UID Number Gets Brand Name, Logo.” The Hindu. April 27, 2010. Retrieved June 12, 2019 (http://www.thehindu.com/news/national/uid-number-gets-brand-name-logo/ article410397.ece?ref=relatedNews)

Banaji, Jairus. 1972. "For a Theory of Colonial Modes of Production." Economic and Political Weekly 7(52):2498-502.

Barbora, Santosh. 2019. "National Register of Citizens: Problems and Politics in Assam." Explorations: E-Journal of the Indian Sociological Society 3(2):3-28.

Bose, Subhas Chandra. 1962. Crossroads: Being the Works of Subhas Chandra Bose 1938-1940. New York: Asia Publishing House.

Castells M. 2009. The Rise of the Network Society: The Information Age: Economy, Society and Culture, Vol. 1. Hoboken, NJ: Wiley-Blackwell.

Chakravarti, Sudip. 2019. "CAA, NRC, and the Assamese Alphabet Soup of Identities." LiveMint.18 December, 2019. Retrieved March 11, 2020 (https://www.livemint.com/opinion/columns/caanrc-and-the-assamese-alphabet-soup-of-identities-11576689038441.html).

Chatterjee, Partha. 1998. "Development Planning and the Indian State." Pp. 82-103 in The State, Development Planning and Liberalisation in India, edited by T.J. Byres. New Delhi: Oxford University Press.

Cohn, Bernard. 1996. Colonialism and Its Forms of Knowledge. Princeton, NJ: Princeton University Press.

Deccan Herald, 2010. “2010: 50 years of India's First Digital Computer.” Retrieved May 23, 2019 (http://www.deccanherald.com/content/52627/2010-50-years-indias-first.html).

Dharmakumar, Rohin, Seema Singh, and N.S. Ramnath. 2013. "How Nandan Nilekani Took Aadhaar Past the Tipping Point." Forbes India, Oct. 8, 2013. Retrieved June 5, 2019 (http:// forbesindia.com/article/big-bet/how-nandan-nilekani-took-aadhaar-past-the-tipping-point/ 36259/0).

ET Bureau. 2014. "Every Second Indian Now Has an Aadhaar Number." Economic Times, March 11, 2014. Retrieved May 16, 2019 (http://economictimes.indiatimes.com/news/politics-and-nation/ every-second-indian-now-has-aadhaar-number/articleshow/31805325.cms).

Gandhi, Shailesh. 2017. “First Define 'Privacy'.” Retrieved February 24, 2020 (https://aadhaararticles.blogspot.com/2017/09/12027-first-define-privacy-by-sailesh.html).

Gopal, Sarvepalli, ed. 1980. Jawaharlal Nehru: An Anthology. Delhi: Oxford University Press.

Industrial Policy Resolution - 1948. Retrieved March 19, 2020 https://shodhganga.inflibnet.ac.in/ bitstream/10603/137016/7/07_chapter_04.pdf

The Indian Telegraph Act (1885). Retrieved June 25, 2019 (http://www.ijlt.in/pdffiles/IndianTelegraph-Act-1885.pdf). 
Koopman, Colin. 2019. How We Became our Data: A Genealogy of the Informational Person. Chicago: University of Chicago Press.

Lepore, Jill. 2018. “MLTalks: How Data Killed Facts.” MIT Media Lab. Retrieved March 12, 2020 (https://www.media.mit.edu/events/mltalks-jill-lepore/).

liveMint. 2018. "What Supreme Court's Aadhaar Verdict Means for You: 10 Points" September 26, 2018. Retrieved June 13, 2019 (https://www.livemint.com/Companies/ cpSHu1fjQ1WvOP8vMi27aL/What-Supreme-Courts-Aadhaar-verdict-means-for-you-10point.html).

Ludden, David. 2005. "Development Regimes in South Asia: History and the Governance Conundrum.” Economic and Political Weekly 40(37):4042-51.

Mahalanobis, Prasanta C. 1950. “Why Statistics?” Sankhya: The Indian Journal of Statistics 10(3):195228.

Mahalanobis, Prasanta C. 1965. "Statistics as a Key Technology.” The American Statistician 19(2): 43-6.

Majumdar, Boria and Nalin Mehta. 2012. Olympics: The India Story. New Delhi: HarperCollins India. Malik, Payal. 2011. An Overview of the Indian Software Industry Profile, R\&D Features and Future, LIRNEasia and University of Delhi India, Brussels, October 19-20, 2011.

Mathew, Basil B. 2014. "Power, Panopticism and Surveillance: A Panoptic Perspective on Aadhaar." Zenith International Journal of Multidisciplinary Research 4(7):120-126.

National Planning Committee. 1988. Report of the National Planning Committee 1938. New Delhi: Indian Institute of Applied Political Research.

Rajagopal, Arvind. 2011. “Notes on Postcolonial Visual Culture." Bioscope 2(1):11-22.

Rajagopal, Arvind. 2009. "Introduction: The Public Sphere in India: Structure and Transformation." Pp. 1-28 in The Indian Public Sphere: Readings in Media History, edited by A. Rajagopal. New Delhi: Oxford University Press.

Rajaraman, Vaidyeswaran. 2012. "History of Computing in India: 1955-2010." Supercomputer Education and Research Center. Retrieved May 30, 2019 (http://www.cbi.umn.edu/ hostedpublications/pdf/Rajaraman_HistComputingIndia.pdf).

Ramanathan, Usha. 2019. "Future of Freedom." Frontline, July 5, 2019. Retrieved June 3, 2019 (https://frontline.thehindu.com/cover-story/article25878618.ece).

Rao, Ursula. 2013. "Biometric Marginality: UID and the Shaping of Homeless Identities in the City." Economic and Political Weekly 48(13):71-77.

Reach Project (2017). India Case Study: Aadhaar-Providing Proof of Identity to One Billion. Toronto: Munk School of Global Affairs, University of Toronto. Retrieved June 14, 2019 (https:// static1.squarespace.com/static/5769a0b5f7e0ab7b91a3362b/t/ 5a2576f5419202014ee6d6b7/1512405956013/INDIA_CaseStudy_ReachProject2017.pdf).

Samaddar, R. 2018. "The NRC Process and the Spectre of Statelessness in India." The Wire, October 25, 2018. Retrieved March 12, 2020 (https://thewire.in/rights/the-spectre-of-statelessness-inindia).

Scott, David. 1995. "Colonial Governmentality.” Social Text 43:191-220.

Sengoopta, Chandak. 2003. Imprint of the Raj: How Fingerprinting was Born in Colonial India. London: Macmillan. 
Sharma, Dinesh C. 2009. The Long Revolution: The Birth and Growth of India's IT Industry. Noida: HarperCollins.

Special Economic Zone. 2015. “About SPEEZ.” Retrieved May 25, 2019 (http://www.seepz.org/ about_us.html).

Subramanium, Ramesh. 2006. "India and Information Technology: A Historical \& Critical Perspective.” Journal of Global Information Technology Management 9(4):28-46.

Unique Identification Authority of India.2009. “Creating a Unique Identity Number for Every Resident in India." UIDAI Strategy Overview. Retrieved June 6, 2019 (http://www.prsindia.org/ uploads/media/UID/UIDAI\%20STRATEGY\%200VERVIEW.pdf).

Unique Identification Authority of India. 2010. Communicating to a Billion: An Awareness and Communication Report. Planning Commission Government of India. Retrieved June 19, 2019 (https://archive.org/stream/AadhaarCommunicatingToABillion/ Aadhaar\%20Communicating\%20to\%20a\%20Billion_djvu.txt)

Vaidyanathan, Geetha. 2008. "Technology Parks in a Developing Country: The Case of India." Journal of Technology Transfer 33:288-95.

\section{NOTES}

1. Mill's volume was less an example of information-gathering than of creating an ideological portrait of British India. Mill himself never visited India, and wrote his book by examining correspondence stored in the India Office in London. I owe this insight to an anonymous reviewer for this paper.

2. A representative example of the latter approach is the Marxist historian Jairus Banaji's claim that "colonialism must be understood in terms of a specific mode of production, neither feudal or capitalist, though 'resembling' both at different levels" (1972). It ought to be pointed out that such formulations were driven by the need to plot the Indian formation within the grid of historical materialism in order to determine the correct political strategy for the moment.

3. David Ludden (1992) has argued persuasively that even the colonial state can be thought of as a "development regime" committed to the idea of state-guided progress for the entire citizenry.

4. In 1955, the Indian Statistical Institute imported India's first digital computer, an HEC-2M machine manufactured by the British Tabulating Machine Company. Two years earlier, researchers at the ISI had built the country's first analog computer (Sinha 2012).

5. I am using "postcolonial" to designate the period 1947-1991. This may seem arbitrary and even idiosyncratic. I lack the space to argue for this use, but will merely say that for me the category of postcoloniality becomes less and less useful as we go beyond liberalization. I prefer to describe (and analyze) 1991to the present as contemporary rather than postcolonial.

\section{ABSTRACTS}

The category of information has been at the heart of notions about citizenship and governance in all modern societies. This paper constructs a genealogy of information and statehood in India by 
examining how information as a governing idea was brought into play in successive stages of contemporary Indian history. This first section provides a broad account of the creation of the Aadhaar card project-that attempts to uniquely identify every citizen in the country-and briefly reviews the controversies it has generated. The second portion of the paper provides historical snapshots that illustrate information's constitutive role in previous versions of the Indian state. Thus, the second section looks at the role information played in constituting colonial government, while the next section examines the nationalist phase in pre-independence India to suggest that information functioned as speculative category that allowed freedom fighters to dream and think the nation. In the fourth section I look at the pre-liberalization period of postcolonial history to trace how information becomes a state "good" that is both strictly controlled and sparsely disseminated while at the same time acting as a spur to a specialized sort of economic activity. Finally, in the fifth and concluding section of the paper, I analyze information's role in emerging India by revisiting the implications of the Aadhaar card in particular and of informational governance in general, by placing both in the context of contemporary political and administrative developments like the National Population Register and the Citizenship Amendment Act.

\section{INDEX}

Keywords: information, Aadhaar, India, genealogy, postcolonial

\section{AUTHOR \\ BISWARUP SEN}

University of Oregon 